\title{
TALIJANSKA OKUPACIJA NA \\ STRANICAMA SPLITSKOG \\ DNEVNOG TISKA
}

\section{Nedjeljka Balić-Nižić i Sanja Roić}

UDK: 329.18:070(497.5 Split)“1941/1943“

Pregledni rad

Sažetak: U vrijeme talijanske okupacije u Splitu su izlazila dva lista - San Marco! Edizione di Spalato i Il Popolo di Spalato. Na njihovim se stranicama ogledaju svakodnevica grada i njegova društvena, politička, kulturna i civilizacijska klima. Clanak donosi kritički uvid u godišta tih publikacija na talijanskom i hrvatskom jeziku, s težištem na kulturološkim prilozima. Ta dva lista, koja su obilježila razdoblje od proljeća 1941. do jeseni 1943. godine, omogućuju i djelomičnu rekonstrukciju ideološkog konteksta splitske svakodnevice toga razdoblja. Međutim, do sada nisu bila detaljnije obrađena ni u talijanskoj ni u hrvatskoj historiografiji.

Ključne riječi: Split, 1941. - 1943., talijanska okupacija, fašizam, dnevni tisak, kultura, svakodnevica

7 jedan dana prije početka rata protiv Kraljevine Jugoslavije - počeo je njemačkim bombardiranjem Beograda 6. travnja 1941., a nastavljen združenim napadom njemačke, talijanske, bugarske i mađarske vojske - oko tisuću je lokalnih Talijana na poziv konzulata napustilo Split i prešlo u Italiju. Istoga dana kad je napadnut Beograd, talijanska je avijacija bombardirala Split - bilo je to svojevrsno upozorenje - da bi devet dana kasnije, nakon što je proglašena Nezavisna Država Hrvatska, motorizirana divizija „Torino“ ušla u grad. U tadašnjoj se europskoj vojno-političkoj konstelaciji vlast fašističke Italije ponadala da će za svagda i u svoju korist riješiti takozvano ,jadransko pitanje“, odnosno nadoknaditi gubitke nastale djelomičnim ostvarenjem odredbi Londonskog ugovora na istočnoj obali Jadrana nakon Prvoga svjetskog rata.

Konzul Arduini odmah je poslao u Rim bilješku o etničkoj prisutnosti Talijana u Dalmaciji. Njegovi podaci kazuju da je u Splitu bilo 2200, u Šibeniku 300, u Dubrovniku 500, a na Krku 1000 pripadnika talijanske nacionalnosti, čemu je - kako je dodao - trebalo pribrojiti još oko 10000 Dalmatinaca porijeklom Talijana, koji su iz različitih razloga i pobuda u vremenu između dva svjetska rata uzeli jugoslavensko državljanstvo. Većina tog 
stanovništva pripadala je nižem srednjem sloju, a tek su se malobrojni bavili slobodnim profesijama ili bili bogati trgovci i zemljoposjednici. ${ }^{1}$

Već 16. travnja za civilnog komesara Dalmacije postavljen je fašistički dužnosnik Athos Bartolucci, a 18. svibnja u Rimu su potpisani ugovori između Kraljevine Italije i Nezavisne Države Hrvatske. ${ }^{2}$ Splićanin Antonio Tacconi, odvjetnik i međuratni predsjednik društava „Dante Alighieri“ i Talijanske kulturne lige, imenovan je 28. travnja civilnim, odnosno općinskim komesarom, a Bruno Nardelli načelnikom grada.

Gradski dnevnik Novo doba, koji je obilježio splitsku svakodnevicu između 1918. i 1941., okupirale su nove vlasti 10. travnja, a njegov posljednji broj tiskan je 22 . travnja. ${ }^{3} \mathrm{U}$ istoj tiskari talijanske vlasti od 29. travnja štampaju list San Marco! Edizione di Spalato. ${ }^{4}$ Čitatelji su u svibanjskim brojevima u nepotpisanim člancima obavještavani o planovima za krunidbu „novog hrvatskog kralja Tomislava II na Duvanjskom polju u Bosni“,, a 3. lipnja objavljen je Tacconijev govor iz kojeg se mogla razabrati namjera da se u gradu s novim fašističkim poretkom obnovi tradicija suživota Dalmatinaca (Hrvata, Srba i Židova) i Talijana iz vremena prije Prvoga svjetskog rata. ${ }^{6} \mathrm{Na}$ tom je tragu komesar za svoga zamjenika postavio Stefana Selema, nastojeći pritom da se u Split vrati što više onih građana koji su ga još ranije bili napustili i otišli u Italiju. Tacconi je bio u dobrim odnosima i s lokalnim biskupom Kvirinom Klementom Bonifačićem. ${ }^{7}$ Split je, dakle, potpao pod talijansku vlast, ${ }^{8}$ a granicom je bio odvojen od svoga prirodnog zaleđa, obale južno od grada i nedalekih otoka Brača i Hvara. Premda su spomenuti Rimski ugovori bili potpisani na rok od 25 godina, brzo se pokazalo da je njegova primjena teško provediva, a do potpisivanja dodatne konvencije o zaštiti prava Hrvata u Splitu i na Korčuli nikada nije ni došlo. Uspostavljene granice između Italije i NDH u Dalmaciji nisu bile pravno potvrđene, premda je vlada u Rimu

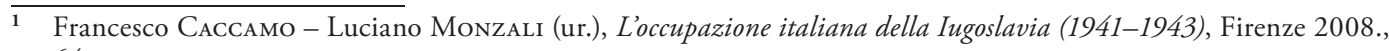
64.

2 Bartolucci ostaje na tom položaju do 7. lipnja, tj. do dana kada je stupio na snagu Guvernatorat Dalmacija. Isto, 65.

3 O posljednjim dramatičnim danima Novog doba usp. Ivanka Kuıć, „Novo doba- najvažniji splitski i dalmatinski list između dva rata", Kulturna baština, 39/2013., 130-132.

4 Do tada je San Marco! izlazio u Zadru, ali to zadarsko izdanje prestaje izlaziti 27. listopada 1941. Splitsko izdanje, kako je istaknuto, ima u svom naslovu uskličnik, što je inače bilo jedno od grafičkih i i stilskih obilježja talijanskih fašističkih publikacija, ali i socijalističkog lista Avanti!. Glavni je urednik bio Antonio Just-Verdus (? - 1985.), raniji urednik zadarskog izdanja. Često se potpisivao kao „šepavi vrag“ („diavolo zoppo“), prijeteći Novom dobu. Studirao je medicinu u Padovi, ali je nije završio. U nekrologu Oddone Talpo piše da je „Nino“ bio vrlo produktivan, odličan govornik i branitelj Zadra, unatoč lakoj tjelesnoj mani. Usp. Rivista dalmatica, 56/1985., br. 1, 69. Drago Gizdić, nasuprot Talpu, piše da su talijanski fašistički okupatori otpočeli izdavati „listić“ San Marco! koji „izlazi na dva jezika, posebno na hrvatskom, posebno na talijanskom, s istovetnim tekstom. Glavni i odgovorni urednik je fašist talijanaš Antonio Just Verdus.“ Drago Gizdić, Dalmacija 1941. Prilozi historiji Narodnooslobodilačke borbe, Zagreb 1959. 142 .

5 Na str. 3. redovno su objavljivane također nepotpisane gradske vijesti pod naslovom „U Palači i oko nje“ (u talijanskom izdanju: „Dentro e fuori del palazzo“). Pod „palačom“ se misli na gradsku vlast. U zaglavlju lista, u oba izdanja, stajala je Mussolinijeva rečenica na talijanskom: „La guerra contro l'Inghilterra continua e continuerà fino alla vittoria. Mussolini.“ U prijevodu: „Rat protiv Engleske se nastavlja i nastavit će se sve do pobjede. Mussolini.“ Luciano Monzali, Antonio Tacconi e la comunità italiana di Spalato, Venezia 2007., 347.

7 Isto, 349. Monzali navodi dokument prema kojem je Bonifačić priželjkivao talijansku vlast u Dalmaciji.

8 Hrvatski autori i najnoviji talijanski (Caccamo, Monzali) pišu o okupaciji, dok stariji talijanski pišu o aneksiji. Usp. Oddone Talpo, Per l'Italia. Centocinquanta anni di storia dalmata (1797-1947), Ancona 1987., 119. Fašistički su dužnosnici u Splitu govorili o oslobođenju. 
već 7. lipnja donijela zakon o aneksiji Dalmacije. ${ }^{9} \mathrm{O}$ tim travanjskim danima 1941. i privremenom izbjeglištvu brojnih talijanskih obitelji na zapadnu obalu Jadrana i njihovom povratku brodom u Split slikovito piše Enzo Bettiza u romanu Egzil:

(...) duboko me uznemirio i razljutio način, iako još nisam imao ni četrnaest godina, na koji su nas neki uspaljeni i bučni fašistoidni Dalmatinci iskrcali iz broda koji je tek bio stigao iz Ancone. Skupili su nas kao ovce u stado i u namjeri da pokažu slavenskoj splitskoj većini da je njihovomu vremenu došao kraj, prisilili su nas da prođemo pustim gradom pjevajući prijeteće iredentističke pjesme (,kunemo se dalmatinskom čašću da među nama neće ostati niti jedan Hrvat"), predvođeni golemim trobojnicama i talijanskom vojnom glazbom. $\mathrm{Na}$ prozorima i na ulicama nije bilo nikoga. (...) Moji talijanski sunarodnjaci koji su sve napustili prije talijanske agresije, našli su sve na mjestu u trenutku povratka: ništa u kući, skladištima, kancelarijama nije bilo provaljeno, ukradeno,

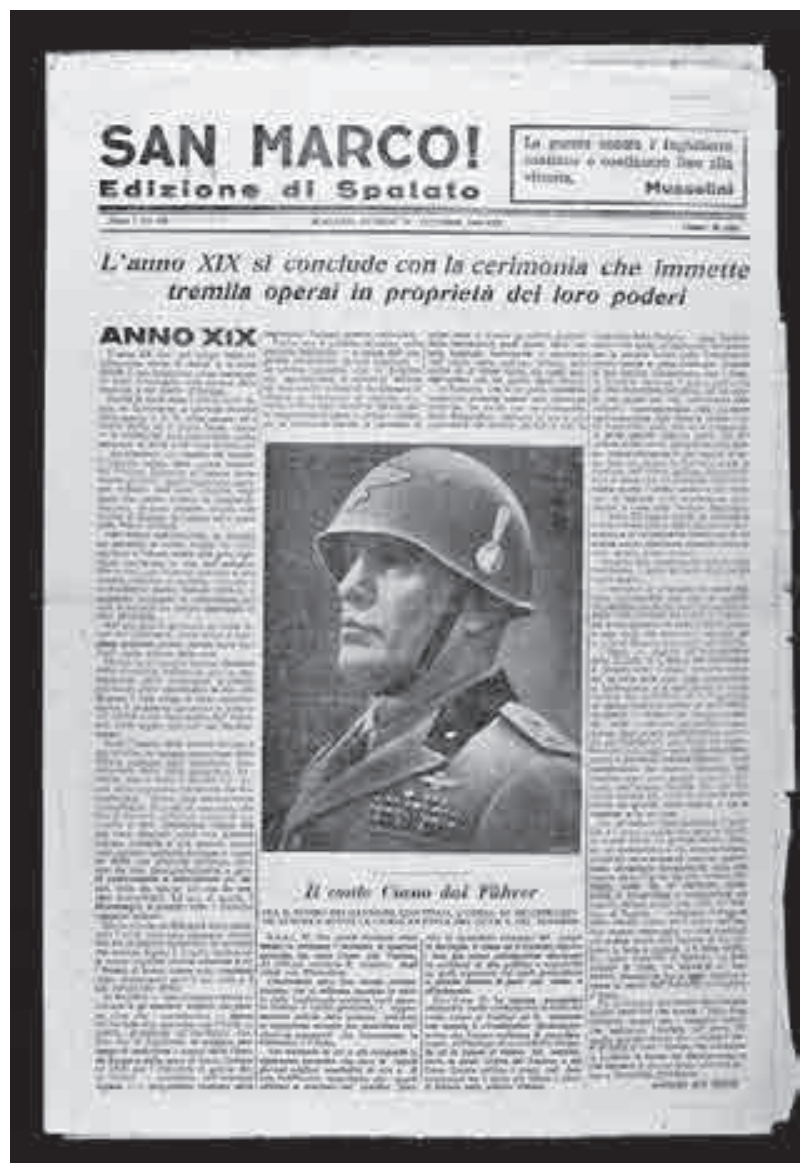

Sl. 1. Naslovnica splitskog izdanja novina San Marco! oštećeno, maknuto, pa ni dirnuto. (...) Hrvatski radnici i namještenici, splitska i vlaška posluga sve su savršeno čuvali i štitili unatoč ratu koji je povela Italija. ${ }^{10}$

Prva 43 broja lista San Marco! Edizione di Spalato izlazila su u dva izdanja, talijanskom i hrvatskom. Od lipnja do posljednjeg broja u studenom 1941. list izlazi u objedinjenom izdanju, s prilozima na talijanskom i na hrvatskom jeziku. Kuriozitet je da su svi toponimi u člancima na hrvatskom navođeni na talijanskom (Spalato, Traù, Bencovazzo, Roma itd.), pa će tako u dnevniku Il popolo di Spalato, koji će nastaviti započetu misiju San Marca!, naslov jednog članka glasiti „Lice Spalata. Novi nazivi gradskih ulica“."

Detaljno se izvještavalo o granici između Italije i NDH u Rimskim ugovorima. U prvom godištu spominje se Tommaseova komemoracija u Settignanu kraj Firence, projekt

9 F. CaCcamo - L. Monzali (ur.), L'occupazione italiana della Iugoslavia, 79.

10 Enzo Bettiza, Egzil, Split 2004., 192 i 195. Poglavlje „Rat“ je na str. 189-257. Istim brodom, Eridania, doplovili su u Split i general Dalmazzo i predstavnici nove fašističke vlasti.

11 Il popolo di Spalato (Split), br. 37, 12. 2. 1942., 2. 
konzervacije Dioklecijanove palače u gradu, ${ }^{12}$ smrt Mussolinijevog sina Bruna prilikom slijetanja borbenog aviona, osuđuje se boljševizam u Rusiji i ismijavaju Churchill i Roosevelt. U oblasti propagande često se javlja Oscar Randi, funkcionar poslan iz Rima, inače jedan od autora promemorije o Dalmaciji pred njezinu okupaciju, napisane za Mussolinija. ${ }^{13}$

Uz političku i gradsku kroniku San Marco! je imao pretenzije da postane književni i kulturološki arbitar u splitskoj sredini, iako je ona bila vrlo dobro upoznata sa suvremenim europskim umjetničkim dostignućima. Na književnim je stranicama lista najprisutniji autor bio stanoviti Igino D’Anversa, inače poštanski činovnik poslan u Split iz Rima, koji je na svom materinskom dijalektu objavio čak 17 pjesničkih sastavaka o splitskoj svakodnevici. ${ }^{14}$ Uz vlastite dojmove D’Anversa piše i o bombardiranju, okupaciji, gradskim spomenicima, posjetu guvernera i dr., najčešće u šaljivom i ironičnom tonu u maniri rimskoga dijalektalnog pjesništva čiji je znameniti predstavnik u 19. stoljeću bio Giuseppe Gioacchino Belli. Od poznatih talijanskih autora bila je prevedena proza Alfreda Orianija (u 53 nastavka) i dramskog pisca imenom Pier Maria Rossa di San Seconda (u 37 nastavaka), a zastupljeni su bili također Giovanni Guareschi i Mario Soldati. ${ }^{15}$ Jedina prevedena novela renomiranoga stranog autora bila je Maupassantov „Prosjak “. ${ }^{16}$ Ostali su autori bili posve nepoznati, među njima i novinar Italoamerikanac Pietro Rossi, tada vojnik u Splitu. Svojevrstan je kuriozitet bila novela izvorno napisana na hrvatskom „U Parizu“, objavljena 10. lipnja 1941. Potpisao ju je gimnazijalac Frane Barbieri, potonji partizan i glasoviti novinar. Zanimljiv su primjer humorističke proze dijalozi stanovitog L. Pecenka, pod skupnim naslovom „Marco i Duje kraj fontane“. U njima je Duje, navodno Talijan, govorio hrvatskom čakavštinom, a Morlak Marco venetskim dijalektom, što je proizvodilo burleskne situacije s lokalnom notom.

I glazbeni je život u tadašnjem Splitu prisutan na stranicama San Marca!: spominje se predstava Traviate sa Zlatkom Radicom u naslovnoj ulozi, pod ravnanjem maestra Drage Savina, von Kleistova farsa Razbijeni vrč u prijevodu Božene Begović i režiji Marka Foteza (lipanj 1941.), operne arije u izvedbi baritona Marušića te Puccinijev Turandot i Verdijev Rigoletto u izvedbi družine „Tespisova kola“17 u rujnu iste godine. U članku objavljenom 7.

12 U tom je projektu sudjelovala i Kraljevska akademija Italije. Usp. Ingrid Brock, „Spalato romana“, Kulturna baština 34/2007., 173-228. Članak na talijanskom jeziku donosi niz arhivskih podataka o projektu restauracije Dioklecijanove palače. U nepotpisanom članku „Progetto di restauro del Palazzo di Diocleziano“ stoji da je za restauraciju bila predviđena svota od 45.276.000 lira. Usp. Il popolo di Spalato (Split), br. 58, 8. 3. 1942., 3.

13 Drugi je autor Luca Pietromarchi, kasnije diplomat Talijanske Republike. O promemoriji usp. Renzo De Felice, Mussolini l'alleato, sv. I. 1: L'Italia in guerra 1940-1943. Dalla guerra „breve“ alla guerra lunga, Torino 1990., 382390.

14 Usp. Nedjeljka BALIĆ-Nižıć, „Un romano de Roma oltre l’Adriatico: versi dialettali sulla Dalmazia di Igino d'Anversa", Adriatico / Jadran. Rivista di cultura tra le due sponde, 3/2007., br. 2, 288-299. Ti su stihovi objedinjeni u knjižici In Dalmazia. Versi in dialetto romanesco u izdanju tiskare Il Popolo di Spalato 1942. godine. Uz godinu je i oznaka „XX“ - dvadeseta godina fašističke ere.

15 Nijedan od autora nije poslije Drugoga svjetskog rata citirao te prijevode u svojim bibliografijama. Usp. Nedjeljka BALIĆ-NižIć, „Lingue e letterature in contatto nel giornale spalatino 'San Marco' (Aprile - Novembre 1941)“, Lingue e letterature in contatto. Atti del XV Congresso dell'IPI, Brunico, 24-27 agosto 2002 (ur. Bart van der Bossche, Marco Bastiansen i Corinna Salvadori Lonergan), sv. 1, Firenze 2002., 395.

16 San Marco! (Split), br. 52, 1. 7. 1941., 7-8. Datum 1. srpnja naveden je kao „1 giulio“, čime uredništvo odaje jezičnu nekompetenciju. Ispravno je „luglio“.

17 Još početkom 1930-ih godina formirani su Carri di Tespi (Tespisova kola), putujuće glumačke družine. One su u malim mjestima i - kao što vidimo - u okupiranim područjima, publici nudili nove kazališne sadržaje. Bila je to vrlo 
srpnja piše se o zagrebačkom uspjehu Paraćeve Adelove pjesme, uz napomenu da je maestro već uglazbio talijanske pjesnike Cavalcantija, Leopardija, Pascolija i D’Annunzija.

Talijanski iredentistički izvori nastoje ublažiti podatke o nasilnoj talijanizaciji (zabranjene su sve netalijanske kulturne udruge) i provođenju fašističke politike na društvenom, političkom i kulturnom planu u Dalmaciji te ih prikazati kao težnju za uspostavom ranijega miroljubivog suživota, no od vremena između dva rata prilike su se znatno promijenile. ${ }^{18}$ Dekretom od 16. svibnja gradonačelnik Tacconi naređuje uporabu talijanskog jezika, pri čemu se ne ukida hrvatski, jer je to naprosto bilo nemoguće provesti u gradu s nadmoćnom hrvatskom većinom. Kao što je navedeno, i lokalni je list bio dvojezičan, ali je u dvojezičnim javnim natpisima talijanski morao imati prednost. ${ }^{19}$ No, dan nakon njemačkog napada na Sovjetski Savez 22. lipnja 1941. na splitskom području počinje izlaziti ilegalno glasilo Naš izvještaj. Uređuju ga splitski ilegalci, članovi Komunističke partije. ${ }^{20}$

San Marco!, međutim, ne piše o demontaži kipa Grgura Ninskog, simbola slavenstva u Splitu, obavljenoj 3. studenog, ali zato izvještava o većem broju učitelja iz Italije koji su trebali preuzeti nastavu u gradskim školama na svim razinama. Ulice su dobile nova imena, dijelom u lokalnoj talijansko-venetskoj tradiciji, dijelom izravno povezana s recentnom fašističkom poviješću Italije.

No, ubrzo su znatno veće ovlasti od lokalnih Talijana u Splitu i samog Tacconija dobili policijski prefekt Zerbino ${ }^{21}$ i federal Cappi sa zamjenikom Mallardom. Potonja trojica provodili su nasilnu talijanizaciju, uveli fašističke organizacije, poput omladinske Gioventù italiana del Littorio (GIL), udruge Opera Nazionale Dopolavoro koja je „bdjela“ nad slobodnim vremenom stanovništva i ženske sekcije Fascio femminile. Koncem prve godine okupacije policijski prefekt izjavljuje da je otpustio 1363 državna službenika hrvatske nacionalnosti ili hrvatskog državljanstva, od njih ukupno 2975, a talijansko je državljanstvo netalijanima dodjeljivano vrlo restriktivno. ${ }^{22}$

uspješna i jako posjećena inicijativa pa je Mussolini u prosincu 1936. proglasio „kazališnu subotu“. P. V. Canistraro smatra da je, premda često na štetu kvalitete, to bila jedna od najuspješnijih režimskih kulturnih inicijativa. Usp. Philip V. Cannistraro, La fabbrica del consenso. Fascismo e mass media, Bari 1975., 114-115.

18 Karakteristično je da talijanska nacionalna enciklopedija Treccani navodi kako je nakon potpisa Versajskog ugovora 8000 Splićana potpisalo peticiju za povrat grada Italiji, ali uopće ne spominje talijansku okupaciju od 1941 . do 1943. godine. Usp. http://www.treccani.it/enciclopedia/spalato_\%28Enciclopedia-Italiana\%29/.

19 Bettiza navodi: „U različitim administrativnim uredima stajao je prijeteći natpis: 'Ovdje se govori talijanski i pozdravlja rimski'. Sjećam se da je tata bijesno vikao: 'Žele ne samo talijanizirati, već lisicama fašizirati u dvadeset i četiri sata tisuću Slavena koji čak ne znaju da se Mussolini zove Benito! To zbilja nije Italija koju smo očekivali!’”E. Betizza, Egzil, 199. O represalijama zbog nepoštivanja ili navodnog nepoštivanja tih propisa usp. Antifašistički Split. Ratna kronika 1941. - 1945. (ur. Marin Kuzmić i dr.), Split 2010.

20 Bili su to Ivan Lučić Lavčević, Leo Geršković, Ante Marasović i Ivan Randić. Naš izvještaj izlazio je do lipnja 1942. a zamijenila ga je Slobodna Dalmacija. Od 1. prosinca 1942. Marasović i Randić uređuju glasilo Sloboda, posvećeno Luki Botiću.

21 Zerbino je došao u Split 1941. kao 35-godišnjak. Il Popolo di Spalato u broju od 1. prosinca 1941., u članku „Vlasti prisustvuju tiskanju prvoga tiska novog splitskog dnevnika“, obavještava: „Prekidamo ovaj izvještaj, pošto će kumica, gospodja Zerbino, do nekoliko trenutaka imati da razbije grlo flaše talijanskog šampanjca, da krsti našu štampariju. "Nakon 8. rujna 1943. Zerbino je postao ministar unutarnjih poslova u vladi Talijanske Socijalne Republike (Repubblica di Salò). Strijeljan je 28. travnja 1945. s Mussolinijem, koji je bježao u Švicarsku. Tijela su im bila javno izložena na trgu Loreto u Milanu.

22 L. Monzali, Antonio Tacconi, 355-356. 
Sedam mjeseci poslije, 30. studenog, izašao je posljednji broj splitskog San Marco!, a 1. prosinca 1941., počinje izlaziti novi list Il Popolo di Spalato („Narod Splita“, prema naslovu Mussolinijevog dnevnika Il Popolo d'Italia iz 1914.). Glavni je urednik bio Talijan Silvio Maurano (1898. - 1977.), dobrovoljac u borbama na Krasu u Prvome svjetskom ratu, prijatelj s futuristima Marinettijem, Carlijem i D’Annunzijem. Potonji mu je nadjenuo nadimak „ludi ardit“. Zajedno su 1919. umarširali u Rijeku, a Maurano se nakon te epizode potpuno posvetio novinarstvu. Bio je u redakcijama brojnih novina bliskih Mussoliniju pa je tako i postavljen za glavnog urednika splitskog dnevnika. ${ }^{23}$

U prvom broju lista (koji uz datum navodi i oznaku godine fašističke ere, XX., a izlazi u 14000 primjeraka), namjesnik (governatore) Giuseppe Bastianini ${ }^{24}$ sa sjedištem u Zadru ističe „plemenitu misiju“ lista da interpretira „osjećaje i težnje u okviru velike talijanske obitelji“ i djeluje kao poveznica s „bratskim gradovima Zadrom i Kotorom“. ${ }^{25}$ Naslovnica je posvećena vanjskoj politici, odnosno uspjesima talijanske i njemačke vojske, druga stranica je posvećena vojnicima, a tek su na trećoj gradske vijesti. Dnevnik donosi gradsku kroniku, obavijesti o promjenama naziva ulica, vijesti o provođenju fašističke politike u gradu (školstvo, ${ }^{26}$ prehrana, stanje na splitskom pazaru - tržnici, predavanja o ratu i o aktualnoj

23 Maurano je nakon rata pisao biografska djela i filmske scenarije, a objavio je i dvije knjige memoara: Ricordi di un giornalista fascista (Sjećanja jednog fašističkog novinara), Milano 1973. i Memorie di un vecchio monello (Sjećanja starog mangupa), Salerno 1994. Prvo izdanje ove knjige tiskano je 1965. godine. U knjizi Ricordi... žali što je iz Rima u Split poslano „najgore ljudstvo“ koje se nije umjelo civilizirano ponašati prema Splićanima. Usp. L. MonZaLI, Antonio Tacconi, 356. Knjige su teško dostupne pa se nadamo da ćemo drugom prigodom moći detaljnije izvijestiti o njihovom sadržaju. Gizdić smatra da je Maurano bio ,jači fašistički glavešina“ od Just Verdusa jer je Il Popolo di Spalato pripremao ofenzivniju propagandnu akciju. Usp. D. Gizdić, Dalmacija 1941, 43 I.

24 Giuseppe Bastianini (1899. - 1961.) bio je kao pouzdan fašist poslan u Rijeku da riješi probleme nastale nakon D’Annunzijeve okupacije. Sudjelovao je u Mussolinijevu pohodu na Rim 1922. Potom ga je ministar vanjskih poslova Ciano zadužio za fašističku organizaciju u inozemstvu. Bio je i ambasador u Londonu. U lipnju 1941. postavljen je za namjesnika Dalmacije. U njegovom životopisu u Biografskom rječniku Talijana stoji da je u Splitu bio „sposoban i realističan, izbjegavao nasilna rješenja i pomagao lokalno stanovništvo i Židove“, dok Monzali tvrdi posve suprotno na temelju arhivskih podataka, tj. da je Bastianini izdao naredbu zabrane ulaska u Split židovskim izbjeglicama iz Hrvatske i Srbije te naredio da ih se predaje ustaškim vlastima. Usp. L. Monzali, Antonio Tacconi, 359. Upravo je Bastianini osnovao zloglasni logor na otoku Molatu. U talijansko Ministarstvo vanjskih poslova vraćen je u veljači 1943., a nakon pada Mussolinijevog režima pobjegao je u Švicarsku. Osuđen je na smrt u odsustvu. Kasnije se ilegalno vratio u Italiju i skrivao u Kalabriji. Procesuiran je 1947. i oslobođen optužbi, a na zahtjev jugoslavenskih vlasti za ekstradiciju nije ni odgovoreno. Napisao je knjigu uspomena u kojoj uopće ne spominje svoje namjesništvo u Splitu i Dalmaciji Volevo fermare Mussolini. Memorie di un diplomatico fascista, Milano 2005.; prvo izd. 1959. Usp. http://www.treccani.it/enciclopedia/giuseppe-bastianini_\%28Dizionario_Biografico\%29/. O njegovim zlodjelima usp. Dokumenti o zločinima talijanskog okupatora, Šibenik 1945., posebno 8-11. Ni poznati talijanski povjesničar, novinar i diplomat Sergio Romano (1929.) nije upoznat s posljedicama Bastianinijevog djelovanja u Dalmaciji pa tvrdi da je štitio Židove u Dalmaciji i kasnije u Solunu. Zamjera mu jedino „suradnju s monarhistom Mihailovićem protiv Titovih formacija“. Usp. „Giuseppe Bastianini un diplomatico nella bufera“, Corriere della sera (http://archiviostorico.corriere.it/2013/ settembre/09/GIUSEPPE_BASTIANINI_DIPLOMATICO_NELLA_BUFERA_co_0_20130909_f1fa48261910-11e3-9477-eeecf424758a.shtml). Noviji arhivski utemeljeni izvori navode da je Bastianini ustanovio Specijalni sud u Dalmaciji (11. listopada 1941.), a 27. lipnja 1942. otvorio je logor na Molatu u kojem je stradalo više od 1000 civila. Ovi podatci dostupni su u njegovu profilu na talijanskoj Wikipediji. Usp. Zdravko DiZDAR, „Italian policies towards Croatians in occupied territories during the WW II", Review of Croatian History, 1/2005., br. 1, 179-210. Il popolo di Spalato (Split), br. 1, 1. 12. 1941., 1.

26 U Split je 1941. poslan „kraljevski providur za škole“, profesor Giovanni Soglian (Šoljan). Registrirana je njegova izjava: „Po njegovoj izjavi hrvatski će jezik igrati u školi posve sporednu ulogu, službeni će jezik biti talijanski, te će se učiti svaki dan. Za hrvatski jezik određena su samo 2-3 sata tjedno. Povijest Hrvatske se uopće neće učiti, nego samo talijanska, a Dalmacija će biti prikazana kao tal. pokrajina, koja se uvijek borila protiv 'barbarskog' utjecaja Hrvata. Bitno će biti promijenjeno i učenje zemljopisa u kome će se Dalmacija prikazivati kao dio Italije. U smislu ovih direktiva izdana je direktorima srednjih škola i okružnica na tal. jeziku broj 945/41 od 27/9. 1941, u kojoj 


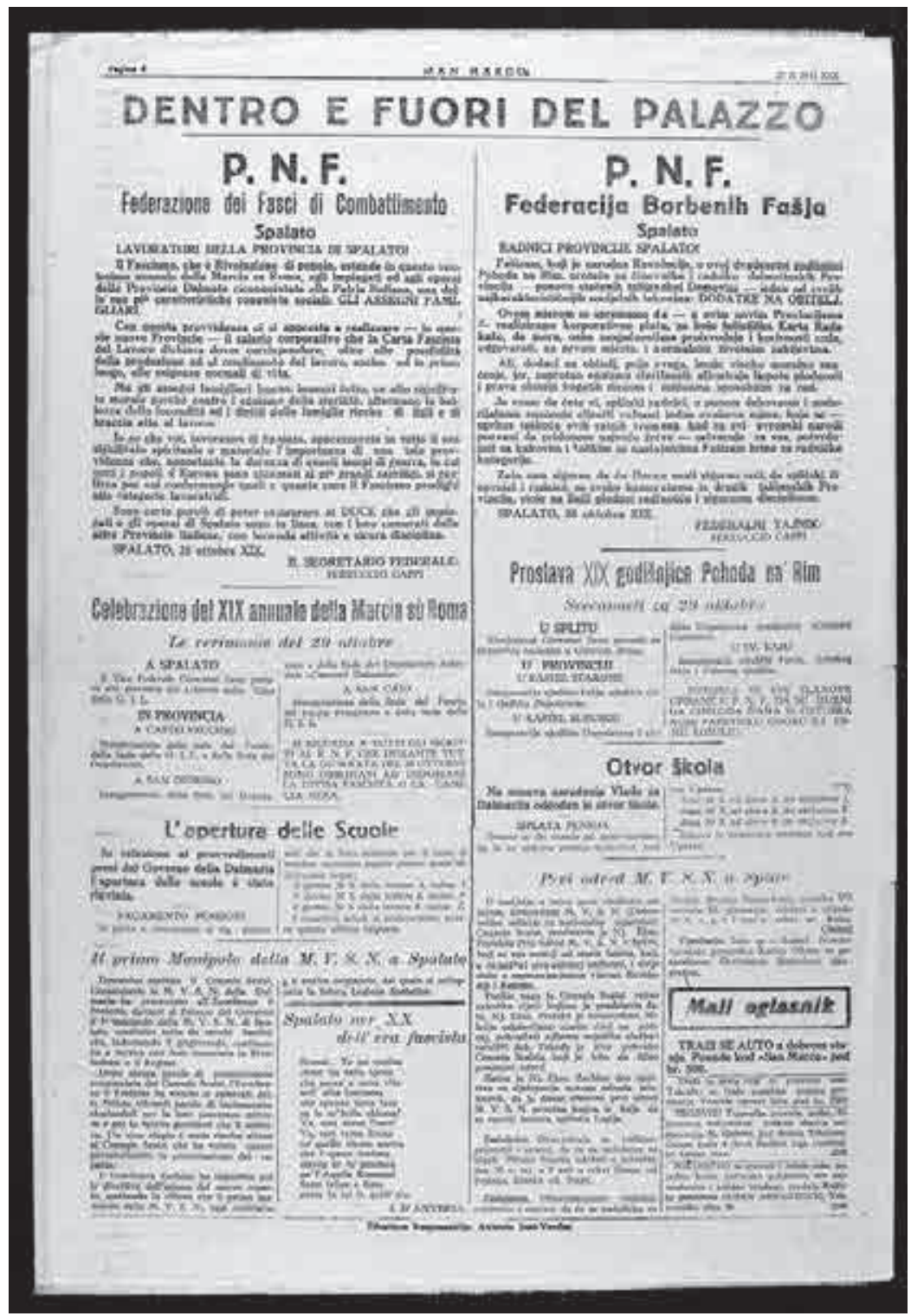

Sl. 2. Iako je San Marco! bio dvojezičan, talijanski je imao prednost i u novinama i u dvojezičnim javnim natpisima

se ponajprije naređuje, da treba 29/9-1941 prirediti 'ceremonijal otvaranja školske godine'. Pod tim ceremonijama se misle neke fašističke parade sa urlikanjem 'Duce' i sličnim kulturnim manifestacijama." Nadalje se u njegovoj okružnici „vrlo živo preporučuje“ upotrebu „u uredu službenog jezika, a koji od dana sastanka direktora splitskih škola (22/9) mora biti samo tal. jezik". Narodnooslobodilačka borba u Dalmaciji 1941-1945. Zbornik dokumenata (ur. Vinko Branica), knj. 1, Split 1981., 227. Rođen u Starom Gradu na otoku Hvaru, Šoljan alias Soglian diplomirao je na Sveučilištu u Bologni, a nakon toga bio lektor talijanskog jezika u Varšavi i ravnatelj talijanskog instituta za kulturu u Sofiji. Objavio je zanimljive lingvističke radove i knjigu Il dalmatico a Cittavecchia sull'isola di Lesina (Zadar, 1937.). Strijeljan je u Splitu 23. rujna 1943. s malobrojnim fašističkim službenicima koji su ostali u gradu. Njegova tadašnja tajnica, učiteljica Maria Pasquinelli, izvršila je 10. veljače 1947. atentat na Roberta de Wintona, savezničkog namjesnika u Puli. 
talijanskoj politici), o uspjesima talijanskih vojnih pohoda i talijanskim doprinosima drugim civilizacijama (između ostalog, i američkoj!), zatim o razlikama britanske i talijanske civilizacije, kao i o „univerzalnom sadržaju“ fašizma. Doznajemo tako, na primjer, da je bila zabranjena prodaja gramofonskih ploča s američkom i engleskom glazbom. U gradskom kazalištu (Teatro comunale), zatvorenom za hrvatski ansambl, primoranom napustiti grad, najavljene su klasične plesne večeri družine Zibina-Jakaša.

Dio članaka objavljen je na hrvatskom jeziku, a kultura je zastupljena prikazima važnih autora iz različitih epoha (renesansni poligraf Poggio Bracciolini, skladatelj Arrigo Boito, Machiavelli, Scipion Afrički, Tit Livije, Toma Arhiđakon, Leonardo da Vinci, Andersen te patriotkinja i političarka iz perioda Napuljske Republike, Eleonora de Fonseca Pimmentel), a zatim i učestalom brigom za arheološku baštinu Splita i Solina, o čemu piše jedna od rijetkih žena suradnica lista, Zadranka Gica Bobich. ${ }^{27}$ Piše se i o rimskim ostatcima u Crnoj Gori, najnovijim iskapanjima u Herkulanumu, kuriozitetima iz zaleđa, odnosno Zagore ili, na talijanskom, Morlacchie, a donose se i vijesti o tečajevima talijanskog jezika ${ }^{28}$ i književnosti (predavanja o Danteu i Carducciju ${ }^{29}$ ) na različitim razinama. Uz ta predavanja, prefekt Zerbino je otvorio ciklus predavanja pod nazivom „Lecturae Ducis“. ${ }^{30}$ Prvi književni tekst, novela futurista Paola Buzzija „Angeli marini“ („Morski anđeli“) objavljen je u tom listu tek u drugom godištu. ${ }^{31}$ Dvojezično je objavljena novela „Bijela mašna na brodu“ futurista Ignazija Scurta ${ }^{32}$ i novela „Kao kad mu je bilo dvadeset godina“ autora Fabia Marie Crivellija. ${ }^{33}$

U broju 46 ističe se vijest iz Rima da će 62000 mladih Hrvata učiti talijanski jer tada talijanski jezik postaje obaveznim predmetom u hrvatskim školama. ${ }^{34}$ Talijanske su vlasti stipendirale dalmatinske Talijane, ali i Hrvate i Srbe koji su željeli studirati u Italiji (dodijeljeno je ukupno oko 300 stipendija). ${ }^{35}$

27 Luigia (Gjica, Gica, Gjika, kako se sve potpisivala) Bobich (1903. - 1986.) bila je među prvim Zadrankama koje su studirale. Diplomirala je ekonomiju i trgovinu na Sveučilištu u Rimu. Mnogo je putovala, pisala članke kulturološkoga ili antropološkog karaktera u raznim časopisima (Touring Club Italiano, francuski Géographie). Nekrolog joj je napisao Mario De Vidovich. Usp. Mario De Vidovich, „Luigia (Gjica) Bobich“, Rivista dalmatica, 57/1987., br. 4, 318-319.

28 Mario Fiorino u svom članku „Alle prese con l'abbici“ („U koštac s talijanskom abecedom“) oduševljeno navodi kako „Spalato italianissima“ („najtalijanskiji Split“) poznaje, doduše, talijanski jezik, ali nažalost dijalektalnu, venetsku varijantu, koju će oko 90 polaznika iz svih društvenih slojeva koji pohađaju tečaj sada moći ispraviti. Glagol biti (tal. essere) uči se ovako: „io sono italiano, tu sei italiano...." (,ja sam Talijan, ti si Talijan..."), a na ploči stoji zapisano: „Viva la Dalmazia italiana! Duce, comanda! Noi ti seguiremo.“ („Živjela talijanska Dalmacija! Duce, zapovijedaj! Mi ćemo te slijediti.") Usp. Il popolo di Spalato (Split), br. 48, 25. 3. 1942., 3.

29 U nepotpisanom članku „L’arte di G. Carducci“ izvještava se o predavanju koje je održao profesor Percy Chirone, na kojem je održana i komemoracija za Niccolòa Gianija, utemeljitelja i prvog ravnatelja Škole fašističke mistike (1930. - 1943.), koji je poginuo na grčkom frontu 14. 3. 1941. Usp. Il popolo di Spalato (Split), br. 65, 17. 3. 1942., 3.

30 Naziv „Čitanja Ducea“ aludira na Lecturae Dantis (čitanja Dantea), uvriježena u talijanskoj kulturi. Usp. Il popolo di Spalato (Split), br. 47, 24. 2. 1942., 3. Zerbino je tom prigodom istaknuo da je izvjesna pobjeda mladih i naprednih naroda.

31 Il popolo di Spalato (Split), br. 10, 11. 1. 1942., 2-3.

32 Il popolo di Spalato (Split), br. 28, 1. 2. 1942., 3.

33 Il popolo di Spalato (Split), br. 40, 15. 2. 1942., 3. Fabio Maria Crivelli (Kopar, 1921. - Cagliari, 2009.), pisac i novinar, vojnik u Drugom svjetskom ratu, odbio je poslušnost nakon pada Italije i bio deportiran u koncentracioni logor u Poljsku, gdje je bio zatočen do oslobođenja. Poslije rata živio je na Sardiniji.

34 Il popolo di Spalato (Split), br. 46, 22. 2. 1942., 4.

35 Koncem 1941. talijansko je Ministarstvo prosvjete osnovalo poseban ured za provedbu talijanizacije u dalmatinskim školama. Hrvatski učitelji morali su polagati ispit iz talijanskog jezika. Prema arhivskim dokumentima Ministarstva vanjskih poslova NDH, navedeno u: Nada Kisıć Kolanović, NDH i Italija, Zagreb 2001., 130-134. 
Između ostalih, list donosi i obavijesti o lokalnim umjetnicima: nekrolog slikaru Mati Meneghellu ${ }^{36}$ i vijest o posthumnoj izložbi njegovih slika u salonu Galić, nekrologe Angjelu Uvodiću i prevoditelju Dantea na hrvatski Antunu Sassu, vijest o „lokalnom Carusu“ Marinu Pavloviću, kompozitoru Francescu Suppéu (Franz von Suppé) te sjećanje na borca za talijanski preporod Dalmacije, Natalea Krekicha i zadarskog povjesničara Lorenza Beneveniu. Spominju se i darovi talijanskih knjiga gradskim knjižnicama.

Piše se i o gradovima koji nisu pod talijanskom vlašću i o njihovom kulturom životu, na primjer o gostovanju talijanske kazališne družine oružanih snaga, ili o filmu Documento Z.3 o djelovanju talijanskih tajnih agenata u Beogradu u ožujku 1941. s poznatom glumicom Isom Miranda u glavnoj ulozi. ${ }^{37}$ Redovan suradnik lista je bivši glavni urednik San Marca! Antonio Just Verdus.

U gradu djeluje specijalni sud, represalije su svakodnevne zbog uskrate fašističkog pozdrava ili odavanja počasti zastavi, a u prostorijama policije 18. travnja mučki je ubijen profesor Ćiro Gamulin, osumnjičen za vezu s komunistima.

Još u veljači 1942. objavljen je članak „I nostri nemici. Il volto di Israele“ potpisan inicijalima A. C. ${ }^{38}$ u kojem se, prema izvještaju talijanskog konzula u Siriji, izvještava o „ritualnom ubojstvu“ svećenika Marrasa, a u ožujku iste godine objavljen je članak o masonstvu i judaizmu kao istinskim krivcima za krizu, ${ }^{39}$ najprije na talijanskom, a četiri dana poslije i na hrvatskom. ${ }^{40}$ Slijedio je članak o osudi Talmuda pape Klementa VIII. (kao što je poznato, iz 17. stoljeća!) i navodnoj činjenici „da su Židovi htjeli rat“. Sve je to bila priprema za uništavanje i pljačku sinagoge u lipnju i deportaciju židovskog stanovništva. ${ }^{41} \mathrm{U}$ gradskoj se sinagogi 10. lipnja 1942. na večernjoj molitvi zateklo pedesetak vjernika kad su u nju upali vojnici i oficiri u crnim košuljama te naredili da svi izađu i prođu kroz špalir vojnika koji su ih nemilosrdno tukli. Nakon što su devastirali i opljačkali hram (umjetničke i vjerske predmete, biblioteku, dokumente, prepisku), vojnici su započeli pljačku židovskih trgovina, knjižare Dalmazia (do rata Morpurgo), parfumerije Luxol, trgovine porculana Finzi i drugih. ${ }^{42}$ Te je događaje oštro osudio talijanski konzul Armellini, ali je ubrzo smijenjen

36 Meneghello, premda javno ožalovan zbog svoga talijanskog prezimena, zapravo je bio suradnik ilegalnog antifašističkog pokreta u Splitu. Usp. Ante SAPUnar - Dora SAPUnAR, „Slikar Mate Meneghello otrgnut zaboravu (12. siječnja 1894. - 2. prosinca 1941.)“, Kulturna baština, 38/2012., 179 - 196.

37 Redatelj filma bio je Alfredo Guarini. Članak „Un film sugli agenti segreti italiani“ potpisan je inicijalima A. F. Usp. Il popolo di Splato (Split), br. 39, 14. 2. 1942., 3. List već od prvog godišta donosi program splitskih kinematografa. Usp. npr. br. 16, 18. 12. 1941., 3. Filmovi su bili projicirani u talijanskom originalu, bez hrvatskog prijevoda.

38 Il popolo di Spalato (Split), br. 47, 24. 2. 1942., 2.

39 Il popolo di Spalato (Split), br. 64, 15. 3. 1942., 3. Članak „Massoneria e giudaismo i veri responsabili“ potpisao je Roberto Ranieri.

40 Il popolo di Spalato (Split), br. 67, 19. 3. 1942., 2. Često su u dnu stranice objavljivane kratke, nepotpisane sentence, a u br. 66, 18. 3. 1942., 2 stoji: „L'ebreo è il nemico che agisce sempre nell'ombra. Quando tende la destra, stringe sempre nella sinistra il pugnale del tradimento." U prijevodu: Židov je neprijatelj koji uvijek djeluje iz sjene. Kad pruža desnicu, u ljevici uvijek stišće bodež izdaje.

41 Talijanski izvori o okupaciji Splita ističu činjenicu da su brojni Židovi s područja pod vlašću NDH migrirali u Dalmaciju i Split i tako se spasili deportacije koja im je prijetila od njemačkih okupatora.

42 Usp. Settimio Sorani, L'assistenza ai profughi in Italia (1933-1941), Roma 1983., 227-231. Židovske izbjeglice (njih oko 1800) koje su dolazile u Split s hrvatskog teritorija bile su vraćene ili internirane na otoke (Brač, Korčula) te u Italiju. U siječnju 1943. splitska je policija dala podatke o rezidentnim Židovima, kojih je u gradu bilo 816. Od njih je 485 pripadalo splitskoj židovskoj zajednici, a ostali su bili izbjeglice. Usp. L. MonZali, Antonio Tacconi, 360. Registriran je podatak da su splitski Židovi tada morali skupiti porez u vrijednosti od 100 milijuna dinara u zlatu i predati vlastima. Usp. Narodnooslobodilačka borba, 449. 


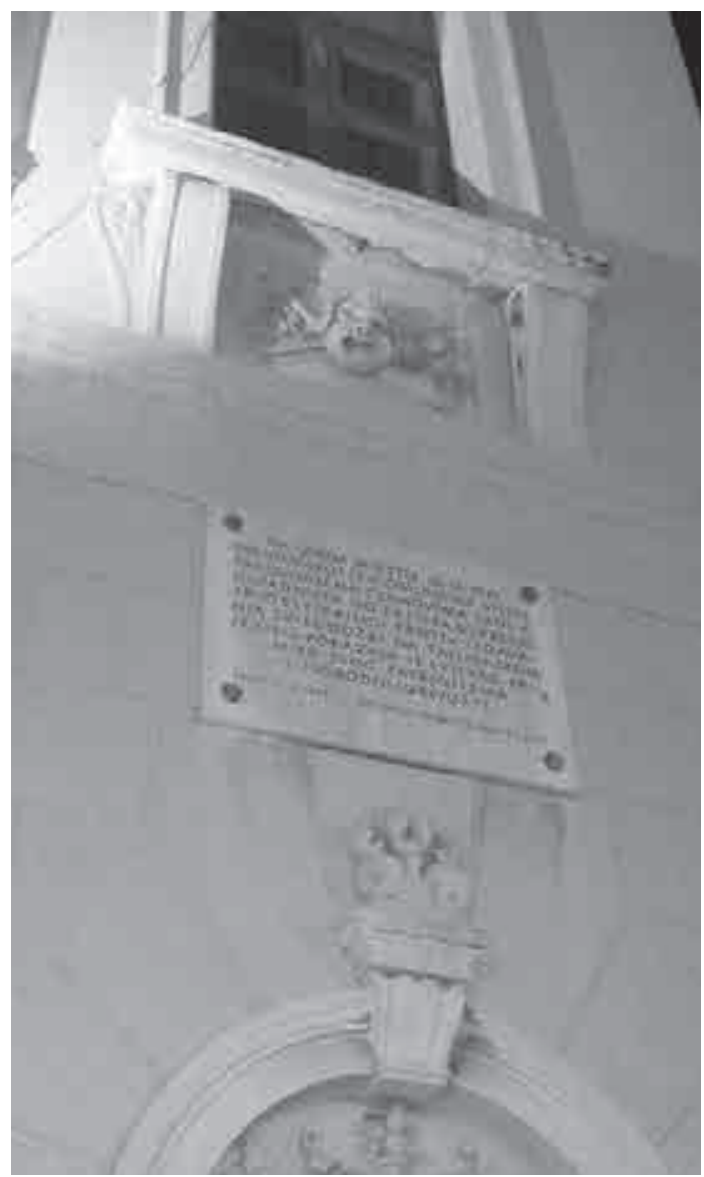

Sl. 3. Spomen-ploča na zgradi Hrvatskog narodnog kazalište u Splitu postavljena u sjećanje na učeničku pobunu protiv izdavanja svjedodžbi na talijanskom jeziku 25. rujna 1941.

jer je Mussolini podržao guvernera Bastianinija i njegove skvadriste. I sam je Antonio Tacconi tražio da se fašistička uprava u gradu smijeni i u tom je razdoblju zaštitio od represalija mnoge splitske obitelji, zbog čega je nakon pada Italije pošteđen te je napustio Split i otišao u Italiju.

Procjenjivalo se da je u gradu, koji je tada brojio oko 60000 stanovnika, bilo više tisuća komunista i komunističkih simpatizera, među kojim su brojne bile žene. Mjesni komitet KPH rukovodio je $s$ tri rajonska komiteta, 18 partijskih ćelija i 164 člana KPH, uz Mjesni komitet SKOJ-a s više stotina članova komunističke omladine. U Solinu je bilo 16 partijskih ćelija sa 68 članova KPJ, u Kaštelima sedam partijskih ćelija sa 90 članova KPJ, a na Šolti su bile četiri partijske ćelije u kojima je bilo obuhvaćeno 20 članova KPH. ${ }^{43}$ No, i dalje je vladala podvojenost između lokalnih, autohtonih Talijana i vojske i službenika prispjelih iz Italije. Domaći su Talijani velikim dijelom bili razočarani i nepovjerljivi, a došljaci su ih nerijetko tretirali kao manje vrijedne, pa čak i vrijeđali govoreći da su „repati Talijani“ ili „talijanska kopilad“. ${ }^{4}$

U drugoj godini izlaženja Il Popolo di Spalato uz političke vijesti, u pravilu objavljivane na naslovnici, piše i dalje o povijesnim ličnostima kao što su Scipion Afrički (paralelno s talijanskim osvajanjima u Africi), zatim Giordano Bruno, a objavljeno je i sjećanje na D’Annunzija. Ponovno se ističe briga talijanskih kulturnih institucija i vlasti za arheološke nalaze u Solinu i za Dioklecijanovu palaču, a važan kulturni događaj je prva izložba splitskih likovnih umjetnika, slikara i kipara. Navode se: Giuseppe Botteri, Antonio Petricic, Rogulic, Fanti, Attilio Carar Battaglia, Stecca, Tolic, Livia Visoina (1900. - 1988.) te Majkowski. Izložbu je 8. lipnja 1942. otvorio prefekt. ${ }^{45}$

43 D. Gizdić, Dalmacija 1941, 157.

44 Oddone TAlpo, Dalmazia una cronaca per la storia (1942), Rim 1985., 1054. Talpo je bio talijanski vojnik, a poslije rata iredentist.

45 O izložbi piše Mario Fiorino. Pandan ovoj bila je ilegalna izložba splitskih umjetnika održana u lipnju 1943. u stanu, odnosno ateljeu kipara Marina Studina (1895. - 1960.), u samom središtu grada. Studin je studirao u Zagrebu, Beču, Pragu i Parizu. 
I sport je bio predmet pokušaja talijanizacije u Splitu. Iz podataka navedenih u godištima dva lista u vremenu talijanske okupacije može se iščitati da su pritisci na sportaše u različitim sportskim disciplinama (plivanje, vaterpolo, košarka, nogomet) da prijeđu u talijanske lige bili neuspješni. ${ }^{46}$

Sadržaj lista mijenja se u trećoj godini izlaženja. Sve su brojniji prilozi s ratnom tematikom, na naslovnici se često nalaze pjesme koje jačaju borbeni moral. Časnici i vojnici pišu dnevničke zapise, komentare i šalju poruke. Od 1. rujna 1943. (tj. od broja 209) umjesto Maurana, koji bježi u Italiju, odgovorni je urednik lista u posljednjih deset dana izlaženja Dalmatinac Ruggero Tommaseo. Predzadnji broj izlazi 9. rujna 1943. na dvije stranice. Na prvoj je dvojezično objavljeno: „Larmistizio. La cessazione delle ostilità contro le forze angloamericane / Primirje. Prestanak neprijateljstva protiv anglo-američkih snaga“. ${ }^{47}$ Zanimljivo je da na drugoj stranici glavni urednik potpisuje članak „Il dalmata Niccolò Tommaseo ultimo difensore della Venezia del '48-'49". U njemu pokušava usporediti preporodni pokret u Veneciji 1848. i borbu protiv Austrijanaca s novonastalom situacijom u Splitu. Time je Ruggero Tommaseo, ${ }^{48}$ potomak bračke obitelji, predaka i slavnoga Šibenčanina - zbog političkog djelovanja u Veneciji, gdje je bio ministar prosvjete, morao je otići u progonstvo na Krf - aludirao na to kako je zapravo on posljednji branitelj talijanskog Splita. Zanimljivo je da su na tim posljednjim stranicama splitskog dnevnika prisutnije vijesti iz hrvatske kulture nego što je to ranije bio slučaj: piše se o kazalištima u manjim hrvatskim gradovima te o prisutnosti talijanske književnosti u Hrvatskoj. Redaktura zakazuje ili je uopće nema pa je tako članak o bombardiranju Rima objavljen na gotovo nečitljivom hrvatskom:

Nahon prvog bombadirania Rome, drugi sastanah orza hod hardinala drzsvnog tainiha. Misli se da je hardenal Magliane izviestio svoie holege o sadasnioj situaciji, a narocito o radu Svetog Oca, posebno s obzirom na Italiu. ${ }^{49}$

46 Detaljni podaci navedeni su u rubrici „Sportski vremeplov“ Slobodne Dalmacije, koja je počela izlaziti 20. ožujka 2000. godine.

47 Il Popolo di Spalato (Split), br. 216, 9. 9. 1943., 1. U hrvatskoj verziji ta važna vijest, objavljena na naslovnoj strani, glasi: „Pretsjednik vlade maršal Badoglio dao je putem radia u 19.45 sati sliedeće saopćenje: talijanska vlada, uvidjevši nemogućnost da nastavi nejednaku borbu protiv nadmoćnih neprijateljskih snaga, a u cilju da prištedi naciji dalje i teže patnje, zatražio je primirje od generala Eisenhowera, glavnog zapovjednika angloameričkih snaga. Traženje je bilo prihvaćeno. U vezi s tim svaki akt neprijateljstva protiv anglo-američkih snaga mora prestati od strane talijanskih snaga u bilo kojem mjestu. Međutim, ove snage reagirat će protiv eventualnih napadaja koji bi došli s bilo koje strane." Vijest je potpisana: Stefani. Ravnatelj talijanske državne Agencije Stefani (utemeljene još 1863.) bio je od 1924. do 1943. Manlio Morgagni (1879. - 1943.), fanatični fašistički novinar koji je počinio suicid na vijest o Mussolinijevu hapšenju u srpnju 1943.

48 Ruggero Tommaseo je 1930-ih godina objavljivao priloge u dalmatinskim novinama na talijanskom jeziku, a napisao je i knjigu o Nikoli Tommaseu. U njoj ga prikazuje pripadnikom isključivo talijanske kulture. Usp. Ruggero Tommaseo, L'ora di Niccolò Tommaseo, Firenze 1933. Sudjelovao je kao dobrovoljac u Prvom svjetskom ratu s bratom Antonom Ferrucciom, koji je u ratu poginuo. Svojom je usporedbom Nikole, branitelja Venecije, i sebe, branitelja Splita, indirektno dodatno naštetio poslijeratnoj recepciji znamenitog Šibenčanina. Poznato je da je nakon Nazorova govora u Šibeniku 18. veljače 1945. uništen Tommaseov spomenik podignut u rodnom gradu uz veliku proslavu 1896. godine. U njoj su sudjelovali brojni Dalmatinci svih nacionalnosti, pa i Nazorovi preci. Jedan drugi Splićanin, liječnik dr. Ivan Tommaseo, priključio se partizanima.

49 Il Popolo di Spalato (Split), br. 216, 9. 9. 1943., 2. List izvještava i o pomoći izbjeglicama sa Sicilije, na koju su se 10. srpnja 1943. iskrcale savezničke snage. 
Il Popolo di Spalato zaključuje svoje izlaženje brojem 217, od 10. rujna 1943., također samo na dvije stranice. Navodi se da ga je uredio ,jedan talijanski oficir antifašist“" (nije potpisan), a da ga je prije štampanja pregledao Ivo Randić, sekretar splitskog komiteta Komunističke partije. Marin Kuzmić navodi da je taj broj tiskan kako bi talijanski vojnici bili što bolje obaviješteni o novonastaloj situaciji u gradu. U cijelosti je prenesen Badogliov brzojav Führeru i vladama Trojnog pakta. U njemu se obrazlaže zašto je Italija bila prisiljena zatražiti primirje. ${ }^{50}$ Potom je objavljen članak pod naslovom „L'Italia si inchina ai combattenti“ (u prijevodu: Italija se klanja borcima). U gradskoj kronici piše se o opskrbi, objavljen je i kino-program, ${ }^{51}$ sudska kronika izvještava o sitnim prekršajima, a na dnu stranice je slika koja prikazuje „naše teško naoružanje u pokretu“.52 Zanimljiv je članak „Islam d’Europa“ (Islam u Europi) suradnice Gice Bobich o Bosni i njezinoj tradiciji. On je vjerojatno još ranije bio pripremljen kao kulturni prilog u listu.

Taj je povijesni događaj, koji se u našoj historiografiji označava kao „pad Italije“, a u talijanskoj kao „primirje“, ušao u jedan hrvatski roman - Dalmacijo, stara Dalmacijo Ivana Katušića. Roman završava konačnim odlaskom splitskog Talijana šjor Bepa i njegovog sina Turidda, talijanskih Dalmatinaca koji se nisu kompromitirali, ali znaju i osjećaju da im ondje više nije mjesto:

Šjor Bepove riječi još jednom su osvijetlile njegovu omiljenu sliku osamljenog Talijana koji hrabro odolijeva nepreglednoj slavenskoj množini što se pruža od jadranskih žala do „tihog tamo Okeana“. Biti Talijan u Italiji bijaše sasvim izvan i ispod njegovog velikog poslanja: da kao hridina bude sam i da sam bude Italija! (...) Pa ipak svaka riječ, svaka gesta oca i sina bijaše izdignuta iznad svog običnog značenja. (...) Kad je iz starog lumina liznuo plamičak, zagrlio sam Turrida te mu prošaptao na uho: - To je posljednji čin exodusa kojim je nenadani, veliki, osamljeni val odnio najljepše dane naše mladosti. ${ }^{53}$

U pregledima talijanskog tiska za vrijeme fašizma tiskanim u Italiji (o čemu se često pisalo sredinom 70-ih godina 20. stoljeća) ne spominju se publikacije u okupiranim zemljama. Odatle se može zaključiti da je talijanska javnost nastojala da ta neuspjela kolonijalna propagandna epizoda što prije padne u zaborav. Američki istraživač Philip V. Cannistraro ističe da je tisak bio najvažniji kanal za Mussolinijevu fašističku propagandu. Godine 1922. provedena je takozvana „novinarska revolucija“, čime je cjelokupni tisak stavljen pod državnu kontrolu. Dok je školski sustav trebao formirati nove generacije, tisak je morao informirati i formirati mase. Jedino su jaki nacionalni dnevnici kao Corriere della sera i torinska La stampa odolijevali do 1927., kad je svim novinarima naređeno da moraju imati iskaznicu PNF-a (Fašističke nacionalne partije). Uz strani tisak namijenjen turistima mogao se kupiti na kioscima u velikim gradovima dok je Talijanima bio nedostupan zbog

\footnotetext{
50 Usp. Marin Kuzmić, „Kako je Split zaboravio jednu važnu spomen-ploču (i borbu s fašistima)“, Telegram (http:// www.telegram.hr/price/kako-je-split-zaboravio-jednu-vaznu-spomen-plocu-i-svoju-borbu-protiv-fasista/) i http:// www.ratnakronikasplita.com/kronika/1943-2\#1943-09-10.

51 Izmedu ostalih, tog je dana prikazan film Manon Lescaut, snimljen 1940. godine, redatelja Carminea Gallonea, s Alidom Valli i Vittoriom de Sicom u glavnim ulogama.

52 Il Popolo di Spalato (Split), br. 217, 10. 9. 1943., 1.

53 Ivan Katušić, Dalmacijo, stara Dalmacijo, Split 1979., 309 i 312. Za ovaj je roman Katušić (1923. - 1985.) dobio Nazorovu nagradu 1980.
} 
čestog doušništva prodavača - jedini izvori nekontroliranih vijesti, uz strane radiostanice, bile su katoličke novine. ${ }^{54}$

Kada je riječ o obilježjima fašističkog mentaliteta, najbolje su ih saželi Umberto Eco ${ }^{55}$ i Cristina Benussi ${ }^{56}$ a to su: rasizam (rasni su zakoni proglašeni 18. rujna 1938.) i kolonijalizam, odnosno teritorijalno širenje, demografski rast, kult nasilja, kult muškosti popraćen prezirom spram žena i spram svakog odstupanja od heteroseksualnosti, mit o svetosti rata u kojem muškarci očituju snagu, žestoki antikomunizam, kult nadčovjeka koji prevladava svaku odgovornost zakonima, svakovrsne manifestacije fašističkog folklora koji inzistira na domoljubnoj simbolici, paradama, sletovima, organiziranim skupovima, zatim kult obitelji, zov krvi i tla, tradicija, sentimentalna književnost, glazba i filmovi te propagandne poruke u tisku ${ }^{57}$ i na radiju.

Mnoge od tih karakteristika očituju se na stranicama splitskih listova San Marco! i Il Popolo di Spalato. Ti su listovi obilježili svakodnevicu grada u vremenu talijanske okupacije. Dok je kratkotrajniji San Marco! bio u većoj mjeri književno-kulturnog karaktera, objavljujući pretežno sentimentalnu prozu ili prigodnu, kadšto polušaljivu poeziju u kojoj stranac denotira obilježja podneblja u kojem se zatekao i šali se na račun homofonije, ${ }^{58}$ Il Popolo di Spalato imao je izraženiju političku i društvenu misiju u stvaranju konsenzusa, a očitovao je tek u neznatnoj mjeri kulturološke ambicije. Oba su lista eksplicitno promovirala talijanizaciju i vrijednosti u ono vrijeme vladajuće fašističke ideologije. Glavni su urednici bili novinari Talijani iz Zadra ili Italije, ali ne Splićani (jedina iznimka je Ruggero Tommaseo, koji je tu dužnost obavljao ni tjedan dana). Oni su služili režimu i u tom smislu slijedili njegovu ideologiju na stranicama ovog dnevnika. Premda je riječ o lokalnim publikacijama, izbor tema, autora i načini na koji su tekstovi bili predočeni javnosti daju dobar uvid u splitsku svakodnevicu od travnja 1941. do rujna 1943..$^{59}$ Ipak, tek se uz pažljiviju kolokaciju pojedinih suradnika ili osoba o kojima je bilo riječi na stranicama dviju novina može formirati preciznija slika društvene, političke, kulturne i civilizacijske lokalne zbilje. Nakon pada Italije 8. rujna 1943., koji Talijani označuju kao posljedicu državnog udara kojim je kralj Vittorio Emanuele III. srušio Mussolinija 25. srpnja 1943., čime je uspostavljena vlade generala Badoglia i nakon čega je uslijedilo „primirje“, odnosno „armistizio“, više ništa neće biti isto. Dana 16. rujna izlazi prvi put u Splitu 28. broj Slobodne Dalmacije, no već se 3. listopada javlja novo, ustaško Novo doba s urednikom Stjepanom Vukušićem, ${ }^{60}$ koje će izlaziti do 22. listopada 1944.

\footnotetext{
54 Godine 1937. u Italiji je izlazio 81 dnevni list, 132 politička časopisa, 3860 časopisa i 7000 župnih biltena. Tek je u studenom 1941. svaki list dobio povjerenika za tajnost naredbi i čuvanje podataka. Usp. P. V. CANNistraro, La fabbrica del consenso, 197.

55 Umberto Eco, Il costume di casa, Milano 1973., 185.

56 Cristina Benussi, L'età del fascismo, Palermo 1978., 28-34.

57 Već 1937. Ministarstvo narodne kulture (Minculpop) zabranilo je 347 publikacija s obrazloženjem da „vrijeđaju javni moral“. Isto, 64.

58 Igino D’Anversa u jednoj od svojih pjesmica navodi da Hrvati za „come?“ kažu „kako?“, a za „questo“ kažu „ovo“ pa bi tako kokoš, kad bi znala govoriti, svakoga jutra rekla: „kako ovo“, u značenju „kakam jaje“. Usp. N. BALIĆ-Nižıć, „Lingue e letterature“, 391. D’Aversa ismijava i glupost Bračana u pjesmici navedenoj u citiranom radu. Isto, $392-393$.

59 Saveznici su se iskrcali na Siciliju 10. srpnja 1943. Na stranicama Il Popolo di Spalato spominje se pomoć tamošnjem stanovništvu.

60 Stjepan Vukušić (1899. - 1944.) postavljen je na mjesto splitskog načelnika, a 1944. osuđen je i strijeljan.
} 
I danas na internetskoj stranici Talijanskog iredentističkog pokreta stoji geografska karta na kojoj je kao talijanski teritorij označena Istra i cijela dalmatinska obala, unatoč konačnoj uspostavi granica između Italije i Jugoslavije, potvrđenoj sporazumom od 10. studenoga 1975., potpisanim u mjestu Osimu kraj Ancone, na zapadnoj obali Jadrana ${ }^{61}$ No, koliko nam je poznato, u Splitu nijedna ulica nije dobila ime po tom važnom dokumentu.

\section{$\cos$}

\section{Italian Occupation on the Pages of Split Daily NeWSPAPERS}

Two newspapers were published during the Italian occupation San Marco! Edizione di Spalato and Il Popolo di Spalato. Their pages reflect the everyday life in the city and its social, political, cultural and civilizational climate. The paper presents a critical insight into the annals of the publications in the Italian and Croatian languages, focusing on cultural articles. The two newspapers, published in the period from spring 1941 to autumn 1943, make possible a partial reconstruction of the ideological context of everyday life in Split during that period, and they have not so far been examined either in Italian or in Croatian historiography in any detail.

Key words: Split, 1941-1943, Italian occupation, fascism, daily press, culture, everyday life

\section{$\cos$}

\section{Izvori i literatura}

Il Popolo di Spalato (Split), 1941. - 1943.

San Marco! Edizione di Spalato (Split), 1941.

Antifašistički Split. Ratna kronika 1941. - 1945. (ur. Marin Kuzmić i dr.), Split 2010.

Nedjeljka BaLıĆ-NIžıć, „Lingue e letterature in contatto nel giornale spalatino 'San Marco' (Aprile - Novembre 1941)“, Lingue e letterature in contatto. Atti del XV Congresso dell'IPI, Brunico, 24-27 agosto 2002 (ur. Bart van der Bossche, Marco Bastiansen i Corinna Salvadori Lonergan), sv. 1, Firenze 2002., 389-401.

Nedjeljka BALIĆ-NIŽIĆ, „Un romano de Roma oltre l'Adriatico: versi dialettali sulla Dalmazia di Igino d'Anversa", Adriatico / Jadran. Rivista di cultura tra le due sponde, 3/2007., br. 2, 288-299.

Cristina Benussi, L'età del fascismo, Palermo 1978.

Enzo Bettiza, Egzil, Split 2004.

Ingrid Ввоск, „Spalato romana“, Kulturna baština, 34/2007., 173-228.

Francesco CaCCAMo - Luciano Monzali (ur.), L'occupazione italiana della Iugoslavia (1941-1943), Firenze 2008. 
Philip V. Cannistraro, La fabbrica del consenso. Fascismo e mass media, Bari 1975.

Renzo De Felice, Gli anni del consenso, Torino 1974.

Renzo De Felice, Intellettuali di fronte al fascismo. Saggi e note documentarie, Roma 1985.

Renzo De Felice, Intervista sul fascismo, Milano 1992.

Renzo De Felice, Mussolini l'alleato, sv. I. 1: L'Italia in guerra 1940-1943. Dalla guerra „breve“ alla guerra lunga, Torino 1990., 382-390.

Oreste Del Buono (ur.), Eia, eia, eia, alalà! La stampa italiana sotto il fascismo 1919-1943, Milano 1971.

Mario De Vidovich, „Luigia (Gjica) Bobich“, Rivista dalmatica, 57/1987., br. 4, 318-319.

Zdravko DizDAR, „Italian policies towards Croatians in occupied territories during the WW II“, Review of Croatian History, 1/2005., br. 1, 179-210.

Dokumenti o zločinima talijanskog okupatora, Šibenik 1945.

Umberto Eco, Il costume di casa. Evidenze e misteri dell'ideologia italiana, Milano 1973.

Drago Gizdić, Dalmacija 1941. Prilozi historiji Narodnooslobodilačke borbe, Zagreb 1959.

Drago Gizdić, Dalmacija 1941-1945, Zagreb 1964.

Ivan Katušić, Dalmacijo, stara Dalmacijo, Split 1979.

Nada Kisıć Kolanović, NDH i Italija, Zagreb 2001.

Ivanka Kuıć, „Novo doba - najvažniji splitski i dalmatinski list između dva rata“, Kulturna baština, 39/2013., 113-138.

Luciano Monzali, Antonio Tacconi e la comunità italiana di Splato, Venezia 2007.

Narodnooslobodilačka borba u Dalmaciji 1941-1945. Zbornik dokumenata (ur. Vinko Branica), knj. 1, Split 1981.

Ante Sapunar - Dora Sapunar, „Slikar Mate Meneghello otrgnut zaboravu (12. siječnja 1894. 2. prosinca 1941.)“, Kulturna baština, 38/2012., 179 - 196.

Settimio Sorani, L'assistenza ai profughi in Italia (1933-1941), Roma 1983.

Oddone TAlpo, Dalmazia una cronaca per la storia (1942), Roma 1985.

Oddone Talpo, Per l'Italia. Centocinquanta anni di storia dalmata (1797-1947), Ancona 1987.

Ruggero Tommaseo, L'ora di Niccolo Tommaseo, Firenze 1933. 